\title{
Family Structure and School Age Children's Achievement in and Attitude to Leadership Value Concepts in Social Studies and Civic Education
}

\author{
Ayo - Vaughan, Adewunmi. $\mathrm{F}^{1, *} \&$ Amosun, Peter. $\mathrm{A}^{2}$ \\ ${ }^{1}$ Department of Curriculum and Instruction, Federal College of Education (Technical), Asaba, Nigeria \\ ${ }^{2}$ Department of Teacher Education, University of Ibadan, Nigeria \\ *Correspondence: Department of Curriculum \& Instruction, Federal College of Education (Technical), Asaba, Delta \\ State, Nigeria. Tel: 234-803-579-2800. E-mail: oluwanikanlomola@gmail.com
}

Received: October 23, 2015

Accepted: March 3, $2016 \quad$ Online Published: April 19, 2016

doi:10.5430/wje.v6n2p92

URL: http://dx.doi.org/10.5430/wje.v6n2p92

\begin{abstract}
Western education in Nigeria led to the involvement of schools in the maintenance of appropriate leadership values. However, appropriate leadership value manifestations among school age children in Nigeria who are the future leaders are lacking. To maintain these values, studies have suggested that the family structure of a child plays an important role. This study, therefore, using two modes of active learning strategies as treatment packages, determined the moderating effect of family structure on school age children's' achievement in and attitude to leadership value concepts in social studies and civic education in Delta State, Nigeria. The study adopted the pre-test-post-test, control group quasi-experimental design. Junior secondary students in Delta state made up the population of the study. Multi-stage and simple random sampling techniques were employed in arriving at the sample. A total of two hundred and sixty - five students made up the study sample. Students' Achievement in Leadership Values Test $(\mathrm{r}=0.90)$ and Students' Attitude to Leadership Values Scale $(\mathrm{r}=0.78)$ were used as instruments for data collection. Data were analysed using Analysis of Covariance, Estimated Marginal Mean and Scheffé Pair-wise Comparism. The findings of the study showed that though family structure has a significant effect on students' achievement in leadership value concepts in social studies and civic education, it is not so for students' attitude. Based on this finding, it was recommended that classroom teachers should take into consideration home background factors in the teaching - learning process and consciously guide the learners into healthy communication and relationships among themselves and the teacher.
\end{abstract}

Keywords: achievement; attitude; family structure; leadership values; school age children

\section{Introduction}

Maintenance of appropriate leadership values has always been important to the development of responsible leaders in the society. Leadership as a concept is one of the world's oldest concerns that cut across human society. It has played an important role in developing groups, societies and nations. Wherever civilization and administration develops, leadership also emerges. Though, concepts of leadership can be traced back to ancient history, definitions and classifications started from the early 20th century. Despite the different classifications and dimensions of leadership, leadership has been and probably will always be an important factor in human society.

Gill (2004) corroborating Armstrong (2001) defined leadership as the personal power to win the hearts and minds of people to achieve a common purpose. Leaders are thus agents of change, persons whose acts affect other people more than other people's act affects them. In addition, Kruse (2013) defined leadership as a process of social influence, which maximizes the efforts of others, towards the achievement of a goal. These varied definitions prove a point that leadership is best defined depending on the context it is found.

Leadership then, is not an absolute. It is fluid and ambiguous. It is about people. It is the art of positively influencing people to follow the attainment of a common goal (Damekaa, 2010). It is in a bid to develop responsible leaders that at the advent of western education in Nigeria, subjects like social studies and later in the 1980's civics now called civic 
education emerged. The National Council for Social Studies (NCSS, 2010) defined social studies as the integrated study of the social sciences and humanities to promote civic competence. Ige (2013) indicated that Adesina and Adeyemi (2007) also linked the definition of social studies to that subject whose goal has traditionally been to educate the young to become effective citizens.

Remarkably, the process of becoming an effective citizen entails acquisition of specific skills and values. This was noted by Ogunsanya (1984) that the purpose of introducing social studies as an integrated subject into the Nigerian curriculum for primary schools and teacher training colleges was premised on the need to cultivate in people the right code of conduct and good citizenship in public and private lives. Solomons (2009) also noted the peculiar nature of Social Studies to confirm Ogunsanya's assertion. Similarly, the Nigerian Educational Research and Development Council (NERDC) introduced civic education curriculum in 2007 on the basis that it was designed to address young Nigerians in their formative years with a view of addressing issues that are important to developing them into responsible citizens (NERDC, 2007). The elements of civic education which are civic knowledge, civic skills and civic disposition suggest that when blended with social studies content would result in the manifestation of appropriate values.

Notwithstanding the effort of western education to maintain appropriate values especially in terms of leadership through the teaching of specific subjects, lapses in school age children's achievement in and attitude to leadership value concepts in social studies and civic education are still being observed in schools and the society at large. Ajiboye, Adu and Amosun (2005) and Adeyemi and Ajibade (2011) have recorded cases of under - achievement in social studies, but there is a rising school of thought that says the real problem with social studies is more of attitudinal modification than under-achievement when one evaluates its objectives. Nonetheless, the affective cognitive theory of attitude which was developed by Rosenberg (1956) and reviewed by Cooke and Sheeran (2004) maintained that there is a strong link between knowledge received (achievement) and attitude manifested. This implies that though the primary objective of social studies and civic education may be developing right attitudes and values necessary for making informed and rational decisions, the place of achievement cannot be over looked.

As regards attitude, Bolarin (2005) pointed out clearly that societal values such as belief in God, detesting laziness, dignity of labour, respect for parents and elders, hospitality, integrity, public spiritedness, respect for authority, hardwork, truthfulness and honesty have started getting eroded. Ndan (2005) in support of the above assertion stated that values paradigm in Nigeria have shifted gradually and cherished core values have been jettisoned both in the society and schools. Fayombo and Aremu (2000); Nnachi (2003) and Ndu (1997) have identified that the rate of occurrence of socio-educational abnormalities such as truancy, sex abuse, impersonation, buying of examination answers and massive dropout from schools, begs for an answer to the question - What do secondary school students place value on? Kobiowu (2006); Enakpoya (2009) and Afolayan and Afolayan (2010) have also identified a prevalent practice of drug abuse among post primary school students, teenagers and even adults in the community. Anochie and Ikpene (2001) also revealed that female secondary school students in Port-Harcourt, Nigeria have high incidence of sexual intercourse and majority of students between the ages of 12 to 15 frequently engaged in sex and had aborted severally. These findings suggest that the values of self control, care, maturity, loyalty, independent mindedness, honesty, integrity, self - control, positive role model and independence are lacking among school age children.

Family structure which implies whether the family is of a monogamous, polygamous or single parent setting has been suggested in literature as one of the variables that affect students learning outcomes. Osunloye (2008) noted that family structure plays an important role in student's educational attainment and social integration. In the view of Ajila and Olutola (2000) this is true because the state of the home affects an individual's psychological development since the family is the first agent of socialization. In terms of single and two parent families, Tenibiaje (2009) and Eweniyi (2005) stated that this type of family setting has a significant influence on students' performance and mental development. On the contrary, the findings of Ushie, Emeka, Ononga and Owolabi (2012) indicated that though parental socio - economic background affects students' academic performance, family structure does not.

As regards family structure and attitude, the family is a unit that can have a powerful influence on molding the attitudes, values and behaviour of children and also for transferring and building social and community values. Similarly, the family could be a source of anxiety, conflict and abnormal changes when there is no stability in the relationship. McDowell and Hosteller (1996) stated that dysfunctional family environment has a negative influence on students' attitude. In the words of Lin (1990), the value orientation of the young child is shaped by the set of values and norms that his immediate family structure transmits. These findings align with that of Maliki and Opukiri (2013) that a strong relationship exists between parents' marital status (family structure) and students' attitude. 


\section{Statement of the Problem}

Maintenance of appropriate values among school age children in order to produce responsible leaders became the responsibility of schools with the introduction of western education in Nigeria. Subjects like social studies and civic education emerged in the bid to achieve this goal. However, school age children's achievement in and attitude to leadership value concepts in social studies and civic education in Nigeria today are questionable because of obvious attitudinal flaws manifested. The reason for these flaws has been partly adduced by several studies to the family structure of the child. Though attempts have been made to curtail attitudinal flaws among school age children, these attempts placed little or no emphasis on the perspective of the effect of family structure. Therefore, this study determined the effect of family structure on school age children's achievement in and attitude to leadership value concepts in social studies and civic education.

\section{Hypothesis}

$\mathrm{H}_{0}$ 1: There is no significant main effect of family structure on students' achievement in leadership value concepts in social studies and civic education.

$\mathrm{H}_{0}$ 2: There is no significant main effect of family structure on students' attitude to leadership value concepts in social studies and civic education.

\section{Methodology}

This study adopted the pretest - posttest, control group, quasi experimental design. The target population for this study was Junior Secondary School Two (JSS II) Social Studies and Civic Education students from public secondary schools in Delta State, Nigeria. The JSS 2 students were involved in the study because the leadership value concepts treated have been fixed in the official curriculum to be taught at this level. Also, the students were not preparing for the external Junior Secondary School Examination, and as such they were much more available to participate in the study. In addition to these, the students are at the formational stage of values development and participating in this study would help define their leadership values orientation very early in life.

Multi Stage sampling technique was used to split Asaba into three clusters based on their senatorial districts from which Delta North senatorial district was randomly selected via ballot. Delta North senatorial district was then split into seven clusters based on the metropolitan nature of its towns. Three towns comprising of Asaba, Agbor and Ogwashi - Uku were then randomly selected via ballot. Six secondary schools were then purposively selected from these towns and randomly assigned to the experimental and control groups for the purpose of this study.

The researchers exposed school age children in experimental group 1 to leadership value concepts using case study learning strategy (treatment 1). The same content was selected and taught for experimental group 2 using puzzle based games learning strategy (treatment 2). The control group was also exposed to the same content using the conventional teaching method. The effect of family structure on the students' achievement and attitude was measured as a moderator variable side by side the application of the treatment. Intact JSS 2 classes sample were selected in each of the six secondary schools that permitted their students' to partake in the study and a total of two hundred and sixty-five (265) students participated.

The main instrument used for data collection was the Students' Achievement in Leadership Values Test (SALVT) and Students' Attitude to Leadership Values Scale (SALVS). The S.A.L.V.T was developed by the researchers to measure the participants' achievement in leadership value concepts. The instrument had two sections; namely, sections A and B. Section A elicited responses on personal information such as: name of school, sex and family structure. Section B consisted of 35 objective test items with options A - D which included only one correct option. These questions covered the three broad concepts of leadership values selected for the study. For reliability, the final draft of the test was administered to an alternate sample and subjected to Kuder Richardson Formula (KR-20) which yielded a reliability coefficient of 0.90 .

The S.A.L.V.S was a 25 item scale developed by the researcher to measure the attitudes of selected secondary school students to leadership value concepts. The scale consisted of two sections; Section A elicited responses on personal details like name of school, sex and family structure. Section B contained 25 scaled statements which consisted of modified Likert 4-point scale of Strongly Agree (SA), Agree (A), Disagree (D) and Strongly Disagree (SD). The scale was designed to measure the following:

a) Attainment of requisite attitudes for identifying leadership related problems and issues in the immediate environment. 
b) Inculcation of the right values that will enable students to actively engage in beneficial leadership values.

c) Development of a sense of moral responsibility in manifesting appropriate leadership values in the immediate environment.

The 25 items drawn were subjected to peer and expert review to determine their appropriateness with reference to the targeted learners. This was used to establish its content validity. The items were tried out on a sample of thirty - five JSS 2 students that were not part of the main study and a reliability coefficient of 0.78 was obtained after subjecting the instrument to Cronbach's Alpha analysis.

\section{Research Procedure}

This study covered a period of ten weeks. The stages involved in carrying out the research are explained below:

Pre-Experimental Activities

The researchers selected and trained three pre - service teachers from the Federal College of Education (Technical) Asaba as research assistants. The research assistants were trained on the nature and purpose of the new teaching strategies. They were informed on the areas where their assistance was needed during the study. Some of these areas are: administration of pre-test and post-test, distribution of study materials, organization of group activities during the puzzle games and case study sessions along with the teacher, observing the teacher and correcting him when erring and other sundry assistance during the study. Preceding this, the researcher visited the schools that were to be selected for the study. The approval of the principal of each school that satisfied the criteria for the selection was sought. One intact class was randomly selected from each participating school.

Recruitment and Orientation of Participating Teachers

Participating teachers were recruited and a Teacher Training Evaluation Sheet was used by the researchers to evaluate the teachers after orientating them. Nevertheless, the teaching subject (social studies and civic education) of the teacher and willingness to participate in the study were of paramount importance. This took place in the first week of the study.

Participating Teachers in the Experimental Schools

The nature and purpose of the study was explained to teachers in these schools. The highlight of the weekly activities to be carried out and the extent of their involvement were also discussed. The teachers were given orientation on how to use the case study and puzzle games strategies to teach and achieve learning objectives.

\section{Participating Teachers in the Control Schools}

These teachers were not trained by the researcher. However, they were informed on how to use the Conventional Teaching Strategy Guide to teach topics in the lesson plan which was designed by the researchers and given out to them. Also, each lesson for the seven (7) weeks was discussed with the teachers to ensure they do not diverge from the contents to be taught.

Administration of Pre-test

A preliminary quantitative survey of the prevailing achievement in and attitude to leadership value concepts of the selected students was carried out at the four (4) experimental and two (2) control schools before the commencement of the activities by administering the pretest. The administration of the pre-test was carried out using the instruments (SALVT and SALVS) prepared for the study. This took place in the second week of the study.

\section{Post Test}

The treatment lasted for seven weeks in the selected schools. Subsequently the Posttest was administered on the experimental and control groups. The SKLVT came first followed by the SALVS. The post test took place on the tenth week of the study.

\section{Data Analysis}

The data collected was analyzed using Analysis of Covariance (ANCOVA) with the pretest scores being used as covariates. The Estimated Marginal Mean (EMM) was employed to determine the magnitude of performances across the groups. The hypotheses were tested at 0.05 level of significance. Where differences were observed in the ANCOVA results, the Scheffé post-hoc test was used to determine the source of variation and direction of significant differences among the groups. 


\section{Results}

$\mathrm{H}_{0}$ 1: There is no significant main effect of family structure on students' achievement in leadership value concepts in social studies and civic education.

Table 1. Summary of 3x3x1 Analysis of Covariance on Students' Achievement

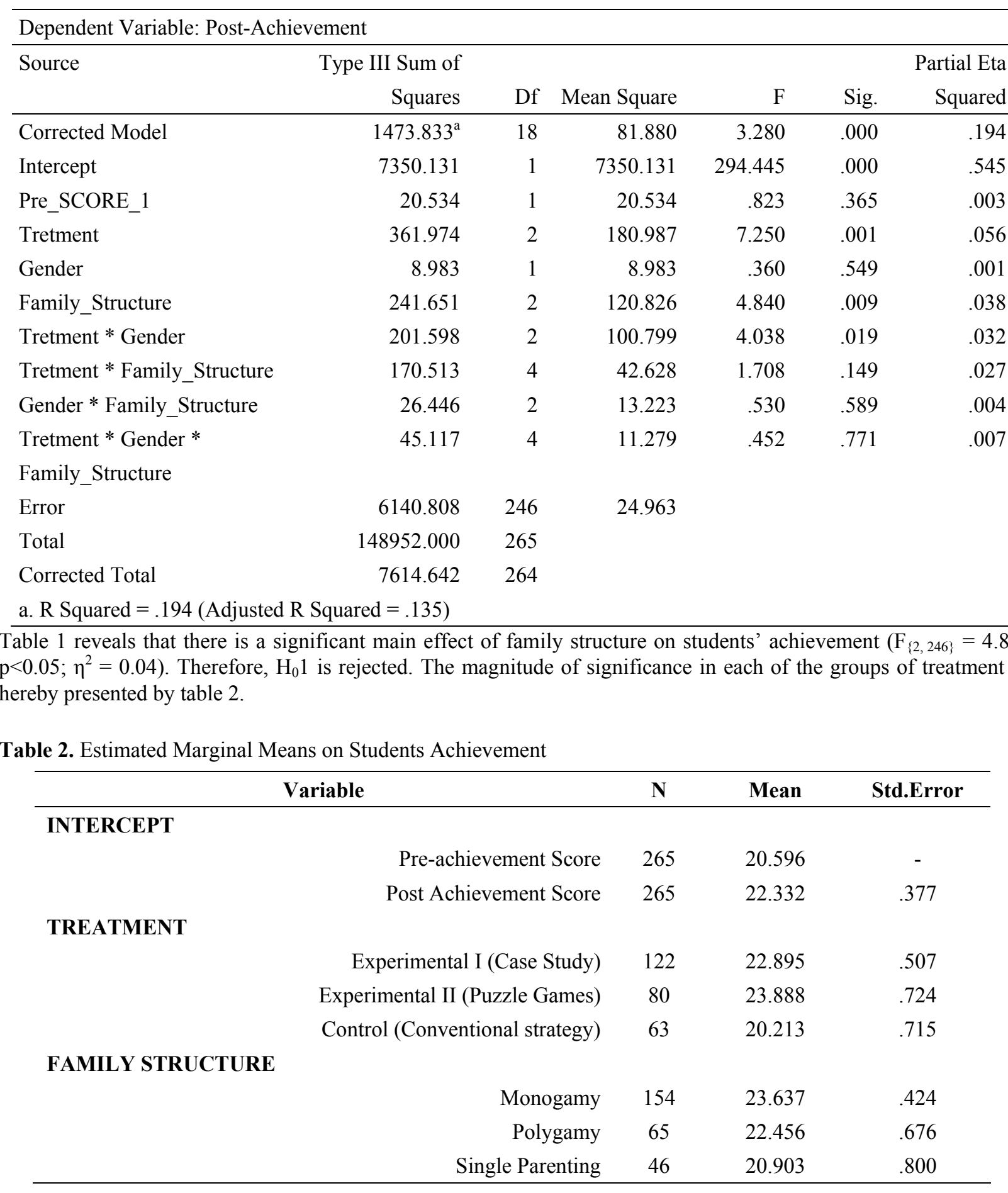

Table 2 showed that students from monogamous family had the highest achievement mean score (23.64), followed by those from polygamous family (22.46) while those from single parenting had the lowest score (20.9). In other to discover the source(s) of the significant effect, table 1.2 presents the Scheffe's pair-wise comparisons. 
Table 3. Scheffe's Pair-wise Comparisons of Students' Achievement among the Family Structures

\begin{tabular}{ccccc}
\hline Treatment & Mean & Monogamous & Polygamous & Single Parenting \\
\hline Monogamous & 23.64 & & $*$ \\
Polygamous & 22.46 & $*$ & \\
Single parenting & 20.90 & $*$ & \\
\hline
\end{tabular}

* Implies that there is a significant difference

Table 3 reveals that the significant difference exposed by table 1 was as a result of the difference between the mean scores of those from monogamous family and those from single parenting. There was no significant difference from those from (i) monogamous family and polygamous family, (ii) polygamous family and single parenting in their achievement scores. This implies that students from monogamous family performed significantly better in leadership value concepts than students from polygamous and single parenting.

$\mathrm{H}_{0}$ 2: There is no significant main effect of family structure on students' attitude to leadership value concepts in social studies and civic education.

Table 4. Summary of $3 \times 3 \times 1$ Analysis of Covariance on Students' Attitude

\begin{tabular}{lrrrrrr}
\hline Dependent Variable: Post attitude & \multicolumn{7}{c}{} & & & & & Partial Eta \\
\hline Source & $\begin{array}{r}\text { Type III Sum } \\
\text { of Squares }\end{array}$ & Df & Mean Square & F & Sig. & Squared \\
\hline Corrected Model & $1177.037^{\mathrm{a}}$ & 18 & 65.391 & .631 & .874 & .044 \\
Intercept & 22727.991 & 1 & 22727.991 & 219.399 & .000 & .471 \\
Preattitude & 119.544 & 1 & 119.544 & 1.154 & .284 & .005 \\
Tretment & 64.314 & 2 & 32.157 & .310 & .733 & .003 \\
Gender & 44.588 & 1 & 44.588 & .430 & .512 & .002 \\
Family_Structure & 127.775 & 2 & 63.887 & .617 & .541 & .005 \\
Tretment* Gender & 115.969 & 2 & 57.984 & .560 & .572 & .005 \\
Tretment* Family_Structure & 339.616 & 4 & 84.904 & .820 & .514 & .013 \\
Gender* Family_Structure & 195.033 & 2 & 97.517 & .941 & .392 & .008 \\
Tretment* Gender * & 137.196 & 4 & 34.299 & .331 & .857 & .005 \\
Family_Structure & & & & & & \\
Error & 25483.628 & 246 & 103.592 & & & \\
Total & 1662877.000 & 265 & & & & \\
Corrected Total & 26660.664 & 264 & & & & \\
a. R Squared =.044 (Adjusted R Squared = -.026) & & & & & \\
\hline
\end{tabular}

Table 4 reveals that there is no significant main effect of family structure on students' attitude to leadership value concepts $\left(\mathrm{F}_{\{2,246\}}=0.62 ; \mathrm{p}>0.05 ; \eta^{2}=.01\right)$. Therefore, $\mathrm{H}_{0} 2$ is not rejected.

\section{Discussions}

Results obtained from the study showed that there is a significant main effect of family structure on students' achievement in leadership value concepts in social studies and civic education. Students from monogamous family structure performed significantly better in leadership value concepts than students from polygamous and single parenting family structures. This finding aligns with that of Osunloye (2008) which stated that family structure plays an important role in student's educational attainment and social integration and that of Tenibiaje (2009) and Eweniyi (2005) who submitted that in terms of single and two parent families, a significant positive influence on students' performance and mental development exists. This finding also gives support to the submission of Ajila and Olutola 
(2000) that the state of the home affects an individual's psychological development since the family is the first agent of socialization. However, this finding negates that of Ushie, Emeka, Ononga and Owolabi (2012) that though parental socio - economic background affects students' academic performance, family structure does not.

Findings from the study showed that there is no significant main effect of family structure on students' attitude to leadership value concepts in social studies and civic education. This finding negates that of Yannis, Athanasios and Kaliopi (2004) which stated that students with single parents or no parents at all exhibited unhealthier attitudes and behaviours than students who grew up with both parents. Similarly, the findings of Maliki and Opukiri (2013) maintained that a significant relationship existed between parental marital status and students' attitude towards drug abuse. Thus, indicating that family structure affects students' attitude. This finding also negates that of Carter (2002) which stated among other things that parents/ family structure has a significant positive impact on students' outcomes throughout the elementary, middle and secondary school years. McDowell and Hosteller (1996) had earlier made an assertion that a dysfunctional family environment has a negative influence on students' attitude.

However, some studies have revealed that despite the family structure of a child, certain factors could interplay and thus make the stability or otherwise in a family setting inconsistent with attitude manifested. Collins (2004) points out three of such factors as parental model, parental attitude and cultural expectation. Phares (2003) also submitted that family environment, particularly, parenting deficits such as inconsistency, harsh discipline, marital conflict, financial constrain, ritual disruption and conflicted siblings relations are factors than can influence a child's attitude especially to drug abuse. To Otieno and Ofulla (2009), socio - economic status of the family is a factor that could affects students' attitude positively or negatively no matter the family setting. Lafinhan and Arowolo (2002) also carried out a study among students of selected secondary schools in Ile-Ife, Osun State of Nigeria and found that the reasons for the negative attitude toward drug abuse among students was that cigarette and alcoholism were common problems among students in that area, and students whose parents had television sets, radio and video were also more involved in the attitude of drug abuse. These submissions suggests why the current study's finding showed that there is no significant main effect of family structure on students' attitude to leadership value concepts in social studies and civic education.

\section{Conclusion}

This study has shown that students from monogamous family structure performed significantly better in leadership value concepts than students from polygamous and single parenting family structures. Thus, indicating that family structure has a significant effect on students' achievement in leadership value concepts in social studies and civic education. However, family structure did not have a significant effect on students' attitude to leadership value concepts in social studies and civic education. The reason for these findings could be adduced to the fact that no matter the family setting of a child, several other overwhelming factors interplay with the attitude the child tends to manifest but the setting of the child's family is important if the child is to perform well in his/her studies.

\section{Recommendation}

Based on the study's findings, it is recommended that classroom teachers should take into consideration home background factors in the teaching - learning process and consciously guide the learners into healthy communication and relationships among themselves and the teacher. This would possibly encourage healthy interactions among students from different family structures and foster the necessary achievement enhancement and attitude modification when they exert influence(s) on one another.

\section{References}

Adesina, A.D.O., \& Adeyemi, B.A. (2007). Teaching to achieve social studies values: a case of re-education of teachers. Retrieved Oct. 10, 2012 from http://www.deta.up.ac.za

Adeyemi, B. A., \& Ajibade, Y. A. (2011). The comparative effects of simulation games and brainstorming instructional strategies on junior secondary school students' achievement in social studies in Nigeria. African Research Review, 5(3), 64-80. http://dx.doi.org/10.4314/afrrev.v5i3.67342

Afolayan, J.O., \& Afolayan, A.M. (2010). Drug addiction and its academic implications among secondary school students in Ilorin south local government of Kwara State, Nigeria. Continental Journal of Pharmacology and Toxicology Research, 3, 11-19.

Ajiboye, S., Adu, S., \& Amosun, W. (2005). Introduction to social studies. A basic text for tertiary institution 
students. Ibadan: educational research and study group.

Ajila, C., \& Olutola, A. (2000). Impact of parents' socio-economic status on university students' academic performance. Ife Journal of Educational Studies, 7(1), 31-39.

Anochie, I.C., \& Ikpene, E.E. (2001). Prevalence of sexual activity and outcomes among female secondary school students' in Port-Harcourt, Nigeria. African Journal of Reproductive Health, 5(2), 63-67. http://dx.doi.org/10.2307/3583431

Armstrong, M. (2001). A handbook of human resource management practice ( $8^{\text {th }}$ ed.). London: Kegan Page Ltd.

Banks, J., \& Glegg, A. (1990). Teaching strategies for the social studies: Inquiry, valuing, and decision-making. New York: Longman.

Barr, R., Barth, J., \& Shermis, S. (1978). The nature of the social studies. Palm Springs, CA: ETC Publications.

Bolarin, T. A. (2005). Education as agent of value clarification and orientation. In values education, Proceedings of the $19^{\text {th }}$ annual congress of the academic of education held at the Lagos state university, Lagos, November $22-$ 26.

Carter, S. (2002). The impact of parent/family involvement of student outcomes: an annotated bibliography of research from the past decade. Retrieved April 22, 2015 from http://eric.ed.gov/?id=ED476296

Collins, G. (2004). Christian counselling: a comprehensive guide. Nav Press. 380 - 384.

Cooke, R., \& Sheeran, P. (2004). Moderation of cognition intention and cognition-behaviour relations: A meta analysis of properties of variables from the theory of planned behaviour. British Journal of Social Psychology, 43, 159-186. http://dx.doi.org/10.1348/0144666041501688

Damekaa, U. (2010). Perception of good leadership among the academics in Nigeria: Case of Benue State University, Makurdi. Academic Leadership Journal, 8(4), 15-19.

Enakpoya, E. (2009). Prevalence of drug abuse among Nigerian adolescents: implication for Counseling. The Counsellor, 26(2), 10-16.

Engle, S., \& Ochoa, A. (1988). Education for democratic citizenship: decision making in the social studies. New York: Teachers College Press.

Eweniyi, G. D. (2005). The impact of family structure on university students' academic performance. M.Ed dissertation submitted to Olabisi Onabanjo University, Ago-lwoye.

Fayombo, G. A., \& Aremu, S. (2000). Drug education and its effects on the educational performance of some adolescents drug abusers in Ibadan. The Counsellor, 18(5), 378-387.

Gill, R. (2004). Leadership in the public sector: issues, challenges and a strategy for action. Paper presented at the 2004 EFMD conference on Public Sector Management Development. Brussels, 3-5 June.

Ige, O.A. (2013). Impact of an action cyber crime prevention programme on secondary school students' learning outcomes in civic education and social studies Ph.D. Thesis. Dept. of Teacher Education. University of Ibadan.

Jarolimek, J. (1990). Social studies in the elementary grades. New York: Macmillan.

Kobiowu, S.V. (2006). The social and academic implications of drug abuse among undergraduates: A case study of the Obafemi Awolowo University, Ile-Ife, Nigeria. International Journal of Psychosocial Rehabilitation, 11(1), $66-68$.

Kruse, K. (2013). What Is Leadership? Retrieved from forbes.com

Lafinhan, K., \& Arowolo, O. (2002). A survey of drug abuse problems among students of selected Secondary schools in Ile-Ife, Osun State. The Nigerian Journal of Guidance and Counselling, 8(1), 182-193.

Lin, R-L. (1990). Perception of family background and personal characteristics among Indian college students. Journal of American Indian Education, 29(3), 15-20.

Maliki, A.E., \& Opukiri, C. (2013). Family background variables and Niger Delta University undergraduates' attitude towards drug abuse. International Journal of Research in Social Sciences, 1(3), 13-17.

Mansaray, A. (1987). Subject matter and human learning in School. Social psychological factors of human learning in school. E. E. Ezewu (Ed.), Leadway Books Ltd.

Mansaray, A. (1991). TEE 141: Social studies methods. Department of Adult Education, University of Ibadan. 
McDowell, J., \& Hostetler, B. (1996). Josh McDowell's handbook on counseling youth: a comprehensive guide for equipping youth workers, pastors, teachers, parents. $300-400$

National Council for the Social Studies (NCSS). (2010). National Curriculum Standards for Social Studies: Introduction. Silver Spring, MD: Author. Retrieved from http://www.socialstudies.org/standards/introduction

Ndan, D. E. (2005). Attitude and values for self reliance and progress in a democratic setting: Educational implication. The Journal of the Academy of Education, 9(1), 54-69.

Ndu, A. N. (1997). Education out of school: a necessary component of the total education system. A. Ali (Ed) Perspectives on crucial issues on Nigerian and African education. Onitsha: Cape Publishers International Ltd.

Nelson, M. (1992). Children and social studies. New York: Harcourt Brace Jovanovich College Publishers.

Nigerian Educational Research and Development Council (NERDC). (2007). UBE Social Studies Curriculum. Abuja. Federal Government Press.

Nnachi, R.O. (2003). The problems of dropouts and intellectual wastage among male children in the school system within the Igbo speaking states. The Nigerian Educational Psychologists, 1(1), $50-60$.

Ogunsanya, M. (1984). Introduction to methodologies of Social Studies. Ibadan: Evans (Nig) Publishers.

Osunloye, A. (2008). Family background and student academic performance. Retrieved April 222014 from http://socyberty.com/education/family-background-and-student-academic-performance/

Otieno, A. O., \& Ofulla, A. V. O. (2000). Drug abuse in Kisumu Town Western Kenya. African Journal of food Agriculture Nutrition and Development, 9(3), 846-858.

Phares, V. (2000). Understanding abnormal child psychology. USA: John Wiley \& son, INC.

Rosenberg, M. (1956). Cognitive structure and attitudinal affect. Journal of Abnormal and Social Psychology, 53, 367-372. http://dx.doi.org/10.1037/h0044579

Solomons, I.D. (2009). A conceptual exploration of the teaching and assessment of values within the south African outcomes-based curriculum. Ph.D Thesis. Faculty of Education, University of the Western Cape.

Tenibiaje, D. J. (2009). Influence of family size and family birth order on academic performance of adolescents in higher institution. Pakistan Journal of Social Sciences, 6(3), 110-114.

Ushie, M. A., Emeka, J. O., Ononga, G. I., \& Owolabi, E. O. (2012). Influence of familystructure on students' academic performance in Agege Local Government Area, Lagos State, Nigeria. European Journal of Educational Studies, 4(2), 22-28.

Yannis, T., Athanasios, P., \& Kaliopi, K. (2004). Relations between family structure and students' health-related attitudes and behaviours. Psychological Reports, 95, 851-858. 